\title{
ECOPISTOR
}

UUW.ECONSTOR.EU

Der Open-Access-Publikationsserver der ZBW - Leibniz-Informationszentrum Wirtschaft The Open Access Publication Server of the ZBW - Leibniz Information Centre for Economics

Josheski, Dushko

\section{Preprint \\ Personnel economics issues: What causes increasing work intensity, and what are the policy responses?}

Suggested Citation: Josheski, Dushko (2014) : Personnel economics issues: What causes increasing work intensity, and what are the policy responses?

This Version is available at:

http://hdl.handle.net/10419/91640

Nutzungsbedingungen:

Die ZBW räumt Ihnen als Nutzerin/Nutzer das unentgeltliche,

räumlich unbeschränkte und zeitlich auf die Dauer des Schutzrechts

beschränkte einfache Recht ein, das ausgewählte Werk im Rahmen

der unter

$\rightarrow$ http://www.econstor.eu/dspace/Nutzungsbedingungen

nachzulesenden vollständigen Nutzungsbedingungen zu

vervielfältigen, mit denen die Nutzerin/der Nutzer sich durch die

erste Nutzung einverstanden erklärt.
Terms of use:

The ZBW grants you, the user, the non-exclusive right to use the selected work free of charge, territorially unrestricted and within the time limit of the term of the property rights according to the terms specified at

$\rightarrow$ http://www.econstor.eu/dspace/Nutzungsbedingungen

$B y$ the first use of the selected work the user agrees and declares to comply with these terms of use. 


\title{
Personnel economics issues: What causes increasing work intensity, and what are the policy responses?
}

\author{
Dushko Josheski ${ }^{1}$ \\ Researcher in the field of applied economics mainly, also covers topics from wide area of macroeconomics, \\ international trade and econometrics. \\ University Goce Delcev-Stip
}

\begin{abstract}
In this paper the issue from personnel economics such as work intensity has been investigated. George Akerlof back in 1976 argued that the real life failed to correspond to the standard general equilibrium model set by Arrow-Debreu. In the real life information is neither complete nor it's costless. In real life workers tend to work in harsh conditions, and put more efforts in order to receive better wages, also they have incentives to educate themselves more, as better educated employees are more productive. More productive means that they work faster as the rat's race to the cheese and faster rats will get to the cheese first and get more cheese than slower rats. In reality workers do not want to share their output with slower workers. But it is because of bad norms that firms sets or taxes that government imposes that workers tend to work suboptimal i.e. work more than what is required in equilibrium, or work less than the equilibrium socially optimal required effort. The problem also arises when firms compare worker and pick "average" worker, nowadays in OECD (rich) countries club, workers tend to get paid more and get spurious data on increased productivity and the measure average effort to be biased, so wage function will then be biased $w=w(\bar{e}, t)$, wage is function of average effort and time needed to produce output.
\end{abstract}

Keywords: Rat race equilibrium, labour market regulation policies, job satisfaction, workers performance

JEL codes: M50, M51, M52

\footnotetext{
${ }^{1}$ Authors email: dushkojosheski@gmail.com
} 


\section{Outline of the alternative explanations for the apparent increase in intensity of work examined by Green (2004).And examination of the degree of empirical support for six hypotheses.}

Green argues that one important explanation for intensification of work lays in technological changes of recent decades like "just in time" (JIT) production methods and total quality management (TQM), which reduce monitoring cost and which are effort biased that is to say; they have increased the marginal productivity of change. Second aspect of JIT and TQM production methods is that closer matching between available labour with required workflow has its consequence to make better productive use of workers as long they supply high effort, while the productivity of low effort workers remained the same or raised much less. High-commitment Human Resource Policies. Human Resource Management and work effort.

These techniques aimed at increased commitment by employees, which is manifested in increased levels of effort. Effort incentives By offering appropriate rewards (performance related pay, bonuses, effort related promotion), employers can induce employees to supply higher levels of effort. Declining Union Power and Raising Job Insecurity which says firms found themselves to reduce costs and raise quality when union power is lower; also work intensification is adjunct of a job loss brought by declining benefit/wage ratio and Sectorial differences manifested in declining public to private sector workers average pay.

From the preceding discussion Greene proposes following six hypotheses that work is more likely to have been intensified at workplaces : 1.that experienced technical and organizational changes 2.that have introduced multiskilling and improved task flexibility.3.that have initiated human resources management techniques designed to endanger greater worker involvement.4.that have increased their usage of effort incentives.5.wher the power unions have decrease 6.where there is rising job insecurity. To test this hypothesis Green used data from cross-sectional Workplace Employee Relations Survey (1998). He specifies model ${ }^{2}$ where dependent variable change in effort is regressed on the variables change in: technology, flexibility, high involvement policies, effort incentives, union power and insecurity. In Table $4^{3}$ Column (1) shows that technical innovations and changes in work organization have positive and significant effect on work intensification in small establishments and large establishments in service sector, consistent with [hypothesis 1], also Column (2) shows strong link between

\footnotetext{
${ }^{2} \Delta \mathrm{E}=\alpha \Delta \mathrm{TECH}+\beta \Delta$ FLEX $+\gamma \Delta$ HIGHINV $+\delta \Delta$ INCENTIVES $+\varepsilon$ UNIONDOWN $+\phi \Delta$ INSECURITY $+\mathrm{u}$

${ }^{3}$ See Appendix 1 (Table 4 \& 6)
} 
increases in task flexibility and work intensification consistent with [hypothesis 2] but reduces the significance of the coefficients.

While the role of changes in work organization, is evident in small establishments especially in production sector. The introduction of high-commitment (involvement initiatives and performance related pay) policies have positive and significant effect in small service enterprises, and performance related is indeed significant factor in large production establishments consistent with[hypotheses 3\&4]. Finding shows that there are different factors that determine effort in small and large establishments. The decline in use of collective bargaining has expected positive association with work intensification consistent with [hypotheses 5]. Still, the impact is not all that well defined because variable is specified too general.

Use of Fix-term workers and part time workers is not associated with effort increase, while use of temporary workers and contractors show has an association with effort increase in larger and in small production establishments, but not in small service sector establishments. This provides weak support for a link between insecurity and hard work consistent with [Hypotheses 6]. Work intensification is higher in public and in service sector than in private sector. From Table 6 (according to 33.5\% managers and 26.3\%workplace representatives) introduction of new technology is the main factor of effort change, followed by changes in work organization which are two most important set of factors that can be identified as having raised work intensity.

\section{Why does Clark (2005) suggest that the recent rise in real wages and lower working hours in most OECD countries may provide a false image of overall labour market performance and job quality?}

Clark (2005) suggests that concentration on rise in real wages and lower working hours can give biased picture of how jobs are perceived by the workers. Overall job satisfaction can be usefully thought as a weighted sum of Job Outcomes. The weights are Job Values, which refer to how much workers care about the different job outcomes. Survey data (International Social Survey Programme-ISSP) in table $2^{4}$ showed that workers (Men\& Women), rate Job security and Job interest as most important job values. Table 3 shows security as most preferable outcome. Clark (2005) uses two sets of data: ISSP multy-country and repeated cross-section and British Household Panel Survey (BHPS); single -country panel.

\footnotetext{
${ }^{4}$ See Appendix 2 Tables $(2,3,4,5,6)$
} 
In Table 4(ISSP), is designed to find out whether overall job satisfaction is higher in 1997 than it was in 1989.In the equation are included set of structural variables such as sex, age, and education. In addition there are country dummies and dummy variable for 1997. Also, wage data are not available for Netherlands in 1997; hours are not available for Hungary in 1989. Therefore there are two specifications: one with and one without wages and hours. The results in column 1 show that coefficient on "1997" variable is negative ,but insignificant, in this column hours and income are not controlled for. This coefficient on 1997 variable is negative and significant in column 2; an employee with same hours and real wage is less satisfied in 1997 than in 1989.In Table 5 takes various measures of job outcome such as: high income, hours preferences, advancement opportunities, secure job, hard work, good job content, good relations at work again there are used two specifications. In row 1 are reproduce the estimated coefficients on the 1997 year dummy form Table 4, hours preference variable is ordered, higher values indicate relative desire for greater hours of work. These findings are similar to base regression, and show that in seven OECD countries, there is little evidence of rise in job quality. Equality feeling of job security fell between 1989 and 1997 and there is no significant change in job content. In this regression a number of measures of job quality have trended downwards.

In Table 6(BHPS) first column shows results from ordered probit estimation of pooled data(as if each observation comes from a different individual) and second column panel data(same individuals are interviewed every year), the estimated coefficients on wave dummies are all negative and jointly significant suggesting overall decline in job satisfaction,1992 is a base year. Results in regressions that are done for other job outcomes and the results are more lees the same in the regressions that do not control for hours. There is negative correlation between job satisfaction and firm size, and job satisfaction minimizes at about 40 in pooled regression.

\section{What is meant by the term rat race equilibrium in Lander et al.? What are the characteristics of large law firms that favour such equilibrium?}

"Rat race" equilibrium is a suboptimum situation in which employees work inefficiently long hours. Given that firms use willingness to work long hours, as an indicator for hiring or promoting employees, issues on adverse selection and asymmetric information may appear in determination of work hours. Employees desiring short hours will have an incentive to camouflage themselves as long hour-worker accepting to work longer they prefer. Firms will respond by establishing work norms with hours long enough to discourage a shot-hour 
employee from pretending to be long-run employee. The result is that employees will work inefficiently long hours; opposite of full information equilibrium situation (Stiglitz 1976); when no actor has incentive to alter his behaviour. Now they will work more hours then utility maximizing number of hours conditional on their wage. Large law firm have simple internal structure i.e. associates and partners.

Promotion decision allows associates to purchase an equity stake in the enterprise. Second and more important feature is that there is always some degree of revenue sharing among partners. Income sharing characteristics of partnerships creates strong incentives to screen potential partners for their propensity to work hard. Rat race equilibrium is expected in any group where group members benefit from the productivity of other group members, the output of the group can be significantly influenced by the work effort of individual members and where the members of group can establish norms. In Table $2^{5}$ nearly $2 / 3(65.41 \%)$ of the associates indicated they would prefer reducing work hours and keeping income unchanged over the coming year. Only $25,56 \%$ of respondents wanted to keep hours unchanged and enjoy $5 \%$ raise in income.

The statistics in Table 2 is not consistent with the conventional labour supply model when a large fraction of associate lawyers are on the backward bending portion of their labour supply curves. However, in the model labour supply elasticity is 10 times larger than reported in the literature. Second, backward bending labour supply curve suggests that associates should cut back their hours as wage rise. In the surveyed firms salaries increase by $7 \%$ per year, but there is no evidence of reduction o billable and non-billable hours among the senior associates. Third, backward bending supply curve suggests associates who want to reduce their hours have, on average, higher income than associates who want to keep their current hours. The data suggests that average income for these two groups is virtually identical. In Panel A(Preferences when others increase hours by $5 \%$ ) in Table 7 we observed that significant number of respondents wanted to increase the desired level of work hours if others were doing the same.

Indeed the hypothesis that the distribution of original hour's preferences was identical with the distribution of preferences when other associates increase work hours is strongly rejected. In Panel B (Preferences when others reduce hours by 5\%). The associates who like their current hours and the desirability of these hours only increased as others reduce hours. And only small

\footnotetext{
${ }^{5}$ See Appendix 3 Tables $2 \& 7$
} 
portion of associates changed their choice. This is consistent with the explanation that associates want to work long hours (Rat race equilibrium hypothesis). Alternatively the explanation might be in the coordination problem; i.e. when associates are working face- to- face $5 \%$ increase in working hours would require other group members to increase hours $5 \%$. Which is not possible because the type of activity consist of solitary library work on legal research in writing and this does not require face-to-face contact.

\section{Summary and answer to a question: Can, and should, labour market regulation or other policies address this issue?}

Technical innovations and new forms of organization have been associated with greater managerial control over the labour process which can bring higher effort levels and are effort biased i.e. productivity is more dependent upon the effort level. Second explanation of work intensification is the use of high commitment policies, and decline in collective bargaining which is found to raise effort.

Job values Clark (2005) shows that are stable, so they are unlikely to explain movements in overall job satisfaction. Overall measures of job outcomes are either flat or falling, despite favourable movements in hours, wages, and job security. Third, there is no evidence of increasing inequality in some measures of job outcomes, as revealed by index of ordinal variation. Also there is no further erosion in job satisfaction gap between union members and non-members in Great Britain, except job security on the union member's side. Satisfaction with work itself has moved sharply downwards Good jobs are being replaced by the bad jobs due to changes in job content.

Another suboptimal solution is "Rat Race" equilibrium when employees work inefficiently long hour's conditional on their wages. Since the overall effect will have detrimental effect upon welfare society labour market regulatory policy should address these issues. Overworking can be restricted by setting maximum hours. The inefficient mix of job outcomes should be changed by increasing the efficacy of Job security and Job Interest, which are valued higher by workers. 


\section{Appendices}

Appendix 1 Table 4

Determinants of Work Intensification , 1993-1998

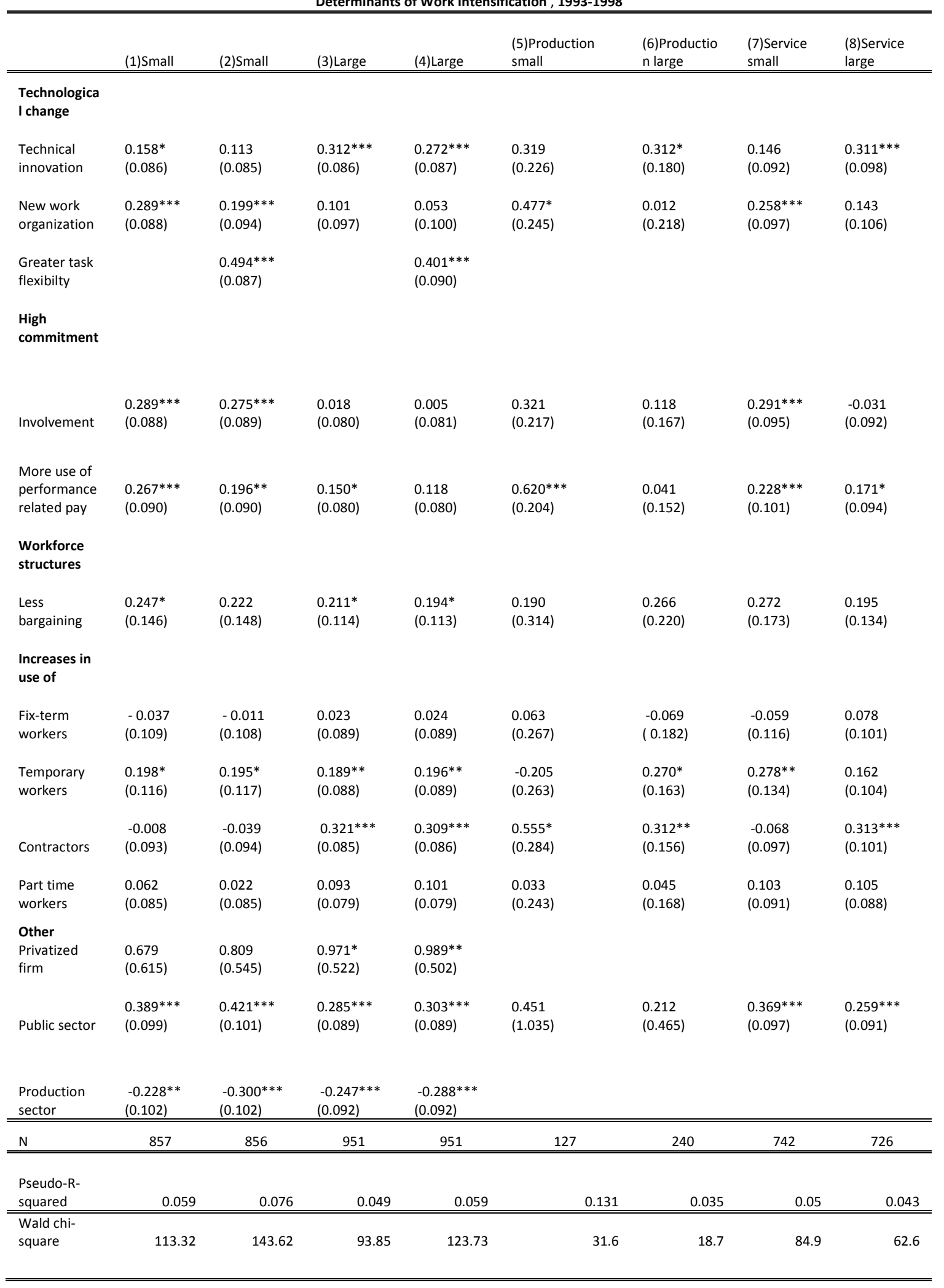


Table 6 Changes with greatest impact on Employees: Respondent's Opinions

\begin{tabular}{lcc}
\hline \hline Changes in: & $\begin{array}{c}\text { According to } \\
\text { managers(Percent of } \\
\text { Establishments) }\end{array}$ & $\begin{array}{c}\text { According to Workplace } \\
\text { Representatives(Percent of } \\
\text { Establishments) }\end{array}$ \\
\hline \hline Payment system & 4.5 & 5.4 \\
$\begin{array}{l}\text { New technology } \\
\text { Working time } \\
\text { arrangements }\end{array}$ & 33.5 & 26.3 \\
$\begin{array}{l}\text { Organization of work } \\
\text { Work techniques and } \\
\text { procedures }\end{array}$ & 7.8 & 17.2 \\
$\begin{array}{l}\text { Introduction of initiatives } \\
\text { to involve employees } \\
\text { Introduction of new }\end{array}$ & 18.6 & 23.6 \\
product or service & 11.2 & 4.1 \\
\end{tabular}

Appendix 2 Table 2 Job Values

\begin{tabular}{|l|c|c|c|c|}
\hline \multicolumn{5}{|c|}{ ISSP 1989-1997 } \\
\hline Job values: Percentage Saying "Very Important" & \multicolumn{2}{c|}{ Men } \\
\hline & 1989 & 1997 & 1989 & 21 \\
\hline $\begin{array}{l}\text { High } \\
\text { Income }\end{array}$ & 19.6 & 18.2 & 23.6 & 15.5 \\
\hline $\begin{array}{l}\text { Flexible } \\
\text { working } \\
\text { hours }\end{array}$ & 20.3 & 20.2 & 14.6 & 20.1 \\
\hline $\begin{array}{l}\text { Good } \\
\text { opportunitie } \\
\text { s for work }\end{array}$ & 23.0 & 20.2 & 24.3 & \\
\hline
\end{tabular}




\begin{tabular}{|l|r|r|r|r|} 
advancemen & & & & \\
\hline Job security & 58.7 & 57.7 & 55.5 & 55.4 \\
\hline Interestng job & 47.9 & 47.8 & 45.3 & 46.9 \\
\hline $\begin{array}{l}\text { Allows to } \\
\text { wrok } \\
\text { independently }\end{array}$ & 29.1 & 31.3 & 33.4 & 33.4 \\
\hline $\begin{array}{l}\text { Allows to } \\
\text { help other } \\
\text { people }\end{array}$ & 23.4 & 25.3 & 16.5 & 16.8 \\
\hline $\begin{array}{l}\text { Useful to } \\
\text { society }\end{array}$ & 25.5 & 23.9 & 21.8 & 16.8 \\
\hline
\end{tabular}


Table 2 British Household Panel Survey

\begin{tabular}{|c|c|c|c|c|}
\hline \multicolumn{5}{|c|}{ BHPS 1991-1999 } \\
\hline \multicolumn{5}{|c|}{ Job values: Percentage Saying CHARACTERISTICS IS MOST IMPORTANT } \\
\hline & Women & & Men & \\
\hline & 1991 & 1999 & 1991 & 1999 \\
\hline $\begin{array}{l}\text { Promotion } \\
\text { prospects }\end{array}$ & 2.1 & 2.4 & 3.6 & 3.3 \\
\hline Total Pay & 13.6 & 19.1 & 19.1 & 25.7 \\
\hline $\begin{array}{l}\text { Good relations } \\
\text { with manager }\end{array}$ & 10.8 & 11.3 & 4.8 & 5.1 \\
\hline Job security & 24 & 17.9 & 35.6 & 31.1 \\
\hline Using initiative & 7.5 & 9.9 & 9.3 & 10.1 \\
\hline Actual work & 34.4 & 31.4 & 24.1 & 33.4 \\
\hline Hours worked & 6 & 6.3 & 1.2 & 1.2 \\
\hline Something else & 1.6 & 1.6 & 2.5 & 1.6 \\
\hline
\end{tabular}


Table3.Job Outcomes

\begin{tabular}{|l|c|c|c|c|}
\hline \multicolumn{5}{|c|}{ ISSP 1989-1997 } \\
\hline \multicolumn{2}{|c|}{ Job Outcomes :Percentage Reporting characteristics in Question } \\
\hline & 1989 & 1997 & 1989 & 1997 \\
\hline Income is high & 15.8 & 16.7 & 25.6 & 25.3 \\
\hline $\begin{array}{l}\text { Prefer to spend less } \\
\text { time in their job }\end{array}$ & 33.7 & 40.3 & 36.2 & 41.5 \\
\hline $\begin{array}{l}\text { Prefer to spend } \\
\text { more time in their } \\
\text { work }\end{array}$ & 13.5 & 9.9 & 11.4 & 10.8 \\
\hline $\begin{array}{l}\text { Opportunities for } \\
\text { advancement is } \\
\text { high }\end{array}$ & 17.6 & 17.9 & 24.3 & 23 \\
\hline Job is secure & 71.8 & 66.4 & 70.9 & 63.8 \\
\hline Hard work & 35.4 & 39.2 & 49.6 & 48.1 \\
\hline Good job content & 40.6 & 46.1 & 38.3 & \\
\hline $\begin{array}{l}\text { Good relations at } \\
\text { work }\end{array}$ & 67.0 & 66.9 & 65.1 & \\
\hline High job & 39.0 & 39.7 & & \\
satisfaction & & & & \\
\hline
\end{tabular}


Table 3 BHPS 1992-1999

\begin{tabular}{|l|c|c|c|c|}
\hline \multicolumn{4}{|c|}{ Job Outcomes: Average Satisfaction and Hours preferences } \\
\hline & 1992 & 1999 & 1992 & 1999 \\
\hline $\begin{array}{l}\text { Satisfaction } \\
\text { with pay }\end{array}$ & 4.93 & 5.00 & 4.56 & 4.82 \\
\hline $\begin{array}{l}\text { Satisfaction } \\
\text { with } \\
\text { security }\end{array}$ & 5.3 & 5.48 & 4.88 & 5.27 \\
\hline $\begin{array}{l}\text { Satisfaction } \\
\text { with work } \\
\text { itself }\end{array}$ & 5.78 & 5.44 & 5.54 & 5.31 \\
\hline $\begin{array}{l}\text { Satisfaction } \\
\text { with hours }\end{array}$ & 5.54 & 5.30 & 5.05 & 4.97 \\
\hline $\begin{array}{l}\text { Overall } \\
\text { Satisfaction }\end{array}$ & 5.75 & 5.45 & 5.27 & 5.17 \\
\hline $\begin{array}{l}\text { Prefer to } \\
\text { work fewer } \\
\text { hours }\end{array}$ & $27.30 \%$ & $31.90 \%$ & $32.50 \%$ & $38.40 \%$ \\
\hline $\begin{array}{l}\text { Prefer to } \\
\text { work more } \\
\text { hours }\end{array}$ & $10.90 \%$ & $7.00 \%$ & & \\
\hline
\end{tabular}


Table 4. Overall Job Satisfaction Regressions . ISSP 1989-1997

\begin{tabular}{|c|c|c|}
\hline & Standard & With income and hours \\
\hline \multirow{2}{*}{1997} & -0.032 & $-0.069 *$ \\
\hline & $(0.022)$ & $(0.027)$ \\
\hline \multirow{2}{*}{ Male } & $-0.068^{* *}$ & $-0.149 * *$ \\
\hline & $(0.021)$ & $(0.029)$ \\
\hline \multirow{2}{*}{30 to 44} & 0.028 & 0.016 \\
\hline & $(0.028)$ & $(0.036)$ \\
\hline \multirow{2}{*}{45 to 65} & $0, .158^{* *}$ & $0.123^{* *}$ \\
\hline & $(0.030)$ & $(0.038)$ \\
\hline \multirow{2}{*}{ Married } & $0.102^{* *}$ & $0.089 * *$ \\
\hline & $(0.024)$ & $(0.030)$ \\
\hline \multirow{2}{*}{ Years of Education } & -0.002 & -0.007 \\
\hline & $(0.003)$ & $(0.005)$ \\
\hline \multirow{2}{*}{ Earnings $(\$ 000)$ per month } & 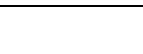 & $0.071^{* *}$ \\
\hline & - & $(0.016)$ \\
\hline \multirow{2}{*}{ Hour per week } & & $0.003^{*}$ \\
\hline & & $(0.001)$ \\
\hline \multirow{2}{*}{ West Germany } & -0.012 & -0.024 \\
\hline & $(0.038)$ & $(0.041)$ \\
\hline \multirow{2}{*}{ Great Britain } & $-0.097 *$ & -0.084 \\
\hline & $(0.038)$ & $(0.040)$ \\
\hline \multirow{2}{*}{ USA } & $0.139 * *$ & $0.124 * *$ \\
\hline & $(0.035)$ & $(0.038)$ \\
\hline \multirow{2}{*}{ Hungary } & $-0.452^{* *}$ & \\
\hline & $(0.038)$ & \\
\hline \multirow{2}{*}{ Netherlands } & $0.109^{* *}$ & \\
\hline & $(0.035)$ & \\
\hline \multirow{2}{*}{ Italy } & $-0.086^{*}$ & $-0.119 * *$ \\
\hline & $(0.039)$ & $(0.044)$ \\
\hline Observations & 10041 & 6468 \\
\hline
\end{tabular}




\begin{tabular}{|l|c|c|} 
Log-Likelihood & -14301.93 & -9302.44 \\
\hline Log-likelihood at zero & -14467.97 & -9366.07 \\
\hline
\end{tabular}

Note : Standard errors in parantheses.* significant at 5\%** significant at $1 \%$

Table 5 Estimated Changes over Time in Various Outcome Measures.

\section{ISSP 1989-1997}

\begin{tabular}{|l|c|c|}
\hline \multicolumn{2}{|c|}{ Estimated coefficient on "1997" } \\
\hline Job & Standard & With income and hours \\
satisfaction & -0.032 & $-0.069^{*}$ \\
\hline Income is & $(0.022)$ & $(0.027)$ \\
high & -0.042 & $-0.088^{* *}$ \\
\hline Hours & $(0.022)$ & $(0.028)$ \\
preferences & $-0.094 * *$ & $-0.094^{* *}$ \\
\hline Opportunities & $(0.022)$ & $(0.028)$ \\
for & & -0.034 \\
advancement & -0.010 & $(0.028)$ \\
are high & $(0.022)$ & $-0.189^{* *}$ \\
\hline & $-0.213^{* *}$ & $(0.028)$ \\
Job is secure & $(0.022)$ & $0.159^{* *}$ \\
\hline & $0.131^{* *}$ & $(0.032)$ \\
Hard work & $(0.024)$ & 0.005 \\
\hline Good job & 0.007 & $(0.029)$ \\
content & $(0.023)$ & 0.047 \\
\hline Good & 0.014 & $(0.033)$ \\
relations at & $(0.026)$ & \\
work & & \\
\hline & & \\
\hline & & \\
\hline
\end{tabular}


Table 6 Overall Job Satisfaction Regressions. BHPS 1992-2002

\begin{tabular}{|c|c|c|}
\hline 1993 & $-0.079 *(0.033)$ & $-0.164 * *(0.042)$ \\
\hline 1994 & $-0.127 * *(0.033)$ & $-0.241 * *(0.054)$ \\
\hline 1995 & $-0142^{* *}(0.033)$ & $-0.256 * *(0.069)$ \\
\hline 1996 & $-0.116^{* *}(0.032)$ & $-0.231 * *(0.085)$ \\
\hline 1997 & $-0.067 *(0.032)$ & $-0.195(0.103)$ \\
\hline 1998 & $-0.171 * *(0.032)$ & $-0.278 *(0.121)$ \\
\hline 1999 & $-0.204 * *(0.031)$ & $-0.355^{*}(0.139)$ \\
\hline 2000 & $-0.206^{* *}(0.031)$ & $-0.333^{*}(0.157)$ \\
\hline 2001 & $-0.169 * *(0.031)$ & $-0.307(0.178)$ \\
\hline 2002 & $-0.200 * * *(0.032)$ & $-0.362(0.197)$ \\
\hline Male & $-0.208^{* *}(0.010)$ & \\
\hline Age & $-0.061 * *(0.003)$ & $-0.009(0.021)$ \\
\hline $\begin{array}{c}\text { Age- } \\
\text { squared/100 }\end{array}$ & $0.079 * *(0.004)$ & $0.014(0.010)$ \\
\hline $\begin{array}{c}\text { High } \\
\text { educaion }\end{array}$ & $-0.208^{* *}(0.014)$ & \\
\hline $\begin{array}{l}\text { Medium } \\
\text { education }\end{array}$ & $-0.153 * *(0.013)$ & \\
\hline Separated & $0.005(0.031)$ & $0.121 *(0.047)$ \\
\hline Divorced & $-0.040 *(0.017)$ & $0.028(0.039)$ \\
\hline Widowed & $0.056(0.040)$ & $0.099(0.103)$ \\
\hline Single & $-0.116^{* *}(0.014)$ & $-0.094 * *(0.033)$ \\
\hline
\end{tabular}




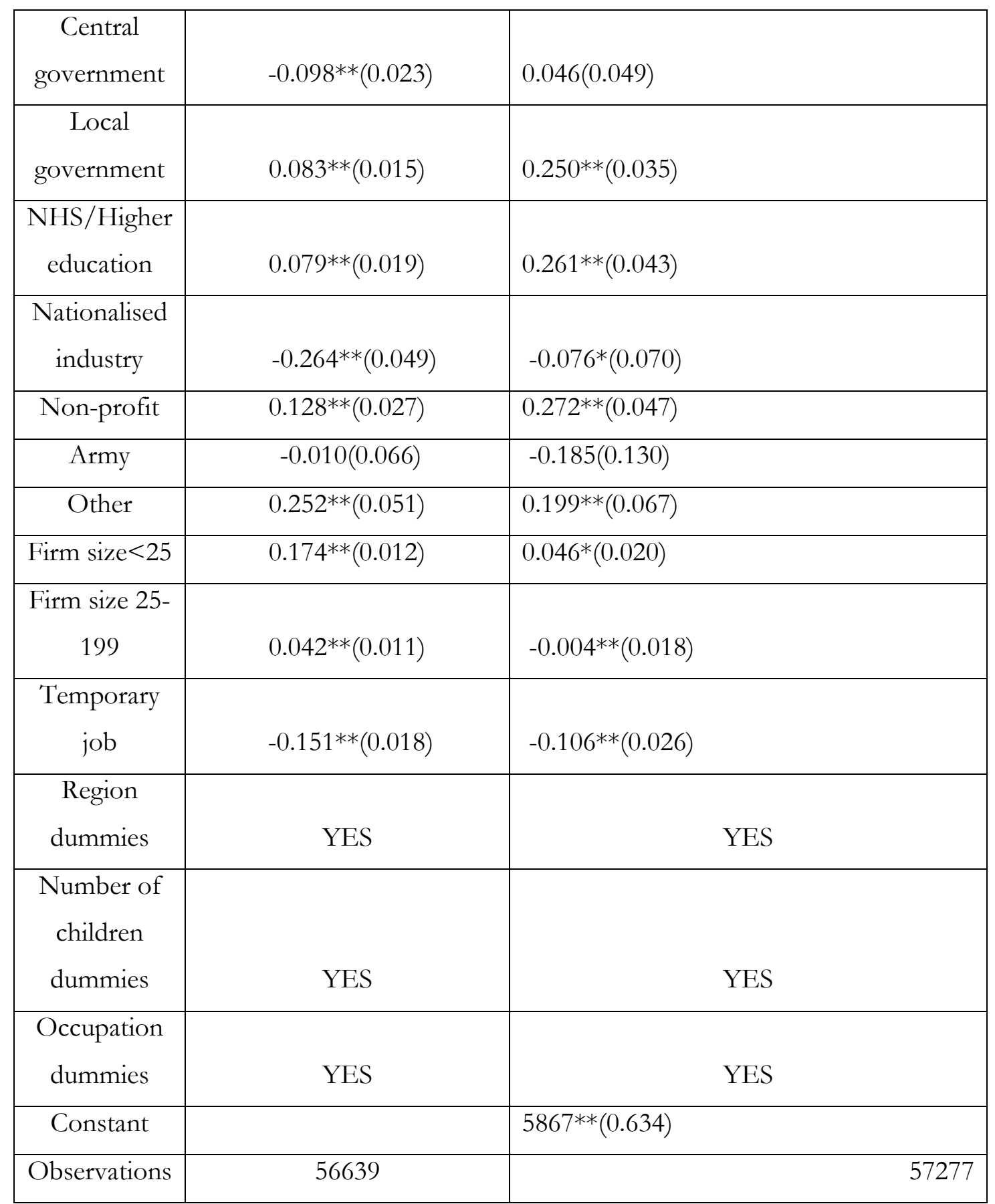

Standard errors in parentheses * significant at 5\%** significant at $1 \%$ 
Appendix 3 Table 2-How Associates Would Choose to Use a Hypothetical 5percent wage increase*

\begin{tabular}{|c|c|c|c|c|}
\hline & & Associates & & \\
\hline & & $\begin{array}{l}\text { Married whose spouse } \\
\text { work full time }\end{array}$ & & \\
\hline Choices & All & With children & No Children & With Children \\
\hline $\begin{array}{l}\text { 1. Reduce billable and } \\
\text { nonbillable work hours by } 5 \text { - } \\
\text { Percent with no change in } \\
\text { annual salary }\end{array}$ & & & & \\
\hline percentage & 65.41 & 60.47 & 78.57 & 76.19 \\
\hline Number of associates & 87 & 26 & 33 & 16 \\
\hline $\begin{array}{l}\text { 2.Continue working the same } \\
\text { number of hours with a 5- } \\
\text { percent increase in annual } \\
\text { salary }\end{array}$ & & & & \\
\hline percentage & 25.56 & 25.56 & 9.52 & 23.81 \\
\hline Number of associates & 34 & 13 & 4 & 5 \\
\hline $\begin{array}{l}\text { 3. Increase billable and } \\
\text { nonbillable work hours by } 5- \\
\text { percent increase with a 10- } \\
\text { percent increase in annual } \\
\text { salary }\end{array}$ & & & & \\
\hline
\end{tabular}




\begin{tabular}{|l|l|l|l|l|}
\hline percentage & 9.02 & 9.02 & 11.90 & 0.00 \\
\hline
\end{tabular}

Panel A :

Droforonroc whon

\begin{tabular}{|c|c|c|c|c|}
\hline Number of associates & 12 & 4 & 5 & 0 \\
\hline Number of Observations & 133 & 43 & 42 & 21 \\
\hline
\end{tabular}

These results ae response to following question:'This question asks you to consider bypothetical five percent change in your work hours over the coming year. You can use the table of the following page to get a sense of what a $5 \%$ change in work hours may mean for you. Please indicate which of the following alternatives you would be most likely to choose " "The table on the following page refers to a chart that presented following calculation. If an associate's average billable and non-billable work hours total 160 hours per month, then 5 -percent change in billable and nonbillable hours would be equivalent to an increase of one eight-hour day per month on 12 eight hour days over 12 months. Similar calculations were presented for associates working 200,240 and 280 hours per month. 


\begin{tabular}{|c|c|c|c|}
\hline & $\begin{array}{l}\text { Reduce hours } 5 \\
\text { percent }\end{array}$ & $\begin{array}{c}\text { Keep current hours } \\
\text { (2) }\end{array}$ & $\begin{array}{c}\text { Increase hours } 5 \text { percent } \\
\text { (3) }\end{array}$ \\
\hline $\begin{array}{l}\text { Reduce hours } 5 \\
\text { percent }\end{array}$ & 51.35 & 0 & 0 \\
\hline Keep current hours & 35.14 & 35.71 & 0 \\
\hline $\begin{array}{l}\text { Increase hours } 5 \\
\text { percent }\end{array}$ & 13.51 & 64.29 & 100.00 \\
\hline Column total & 100.00 & 100.00 & 100.00 \\
\hline $\begin{array}{l}\text { Number of } \\
\text { Observations }\end{array}$ & 37 & 14 & 6 \\
\hline $\begin{array}{l}\text { Panel B: } \\
\text { Preferences when } \\
\text { others reduce } \\
\text { hours }^{c}\end{array}$ & $\begin{array}{c}\text { Reduce hours } 5 \\
\text { percent (1) }\end{array}$ & $\begin{array}{c}\text { Keep current hours } \\
(2)\end{array}$ & $\begin{array}{c}\text { Increase hours } 5 \text { percent } \\
\text { (3) }\end{array}$ \\
\hline $\begin{array}{l}\text { Reduce hours } 5 \\
\text { percent }\end{array}$ & 100.00 & 15 & 0.00 \\
\hline Keep current hours & 0 & 85 & 16.67 \\
\hline $\begin{array}{l}\text { Increase hours } 5 \\
\text { percent }\end{array}$ & 0 & 0 & 83.33 \\
\hline Column total & 100.00 & 100.00 & 100.000 \\
\hline $\begin{array}{l}\text { Number of } \\
\text { Observations }\end{array}$ & 50 & 20 & 6 \\
\hline
\end{tabular}

Table 7 -Changes in Hours Preferences of Associates as the Distribution of Hours in the Firm Shifts

a This is how associates would choose to respond to a 5 -percent wage increase

b This is how associates would choose to respond to a 5 -percent wage increase if the majority of other associates in the firm increased hours by 5 -percent

c This is how associates would choose to respond to a 5-percent wage increase if the majority of other associates reduced hours by 5 percent.

\section{References}


1. Akerlof,G.,(1976), The economics of caste and of the Rat race and other woeful tales, The quarterly journal of economicsVol.90 no.4

2. Clark, A.E. (2005), "Your Money or Your Life: Changing Job Quality in OECD Countries",British Journal of Industrial Relations, No. 43, pp. 377-400.

3. Green, F. (2004), "Why has effort become more intense?", Industrial Relations, Vol. 43, pp. 709-41.

4. Landers,R., Rebitzer,J., Taylor,L.,(1996) "Rat Race Redux: Adverse Selection in the Determination of Work Hours in Law Firms," American Economic Review, 86 (June 1996): 329-48. 